Article

\title{
University Contributions to the Circular Economy: Professing the Hidden Curriculum
}

\author{
Ben Tirone Nunes ${ }^{1}$, Simon J. T. Pollard ${ }^{1}$, Paul J. Burgess ${ }^{1}$ (D), Gareth Ellis ${ }^{2}$, \\ Irel Carolina de $\operatorname{los} \operatorname{Rios}^{1}$ and Fiona Charnley ${ }^{3, *}$ \\ 1 School of Water, Energy and Environment, Cranfield University, Bedfordshire MK43 0AL, UK; \\ mail@benjamintironenunes.com (B.T.N.); s.pollard@cranfield.ac.uk (S.J.T.P.); \\ P.Burgess@cranfield.ac.uk (P.J.B.); i.hdelosrios@gmail.com (I.C.d.l.R.) \\ 2 Energy and Environment Team, Facilities, Cranfield University, Bedfordshire MK43 0AL, UK; \\ r.g.ellis@cranfield.ac.uk \\ 3 Centre for Competitive Creative Design (C4D), Cranfield University, Bedfordshire MK43 0AL, UK \\ * Correspondence: f.j.charnley@cranfield.ac.uk; Tel.: +44-1234-750-111
}

Received: 15 May 2018; Accepted: 20 July 2018; Published: 2 August 2018

\begin{abstract}
In a world dominated by linear economic systems, the road to improving resource use is multi-faceted. Whilst public and private organisations are making progress in introducing sustainable practices, we ask ourselves the extent to which education providers are contributing to the circular economy. As engines for skills and knowledge, universities play a primary role in propelling circular economy approaches into reality and, as such, hold the potential for raising the bar on sustainable performance. A rapid evidence assessment (REA) was therefore undertaken to examine the interactions between university estate management and the circular economy. This assessment identified six pertinent themes: campus sustainability, the hidden curriculum, environmental governance, local impact, university material flows, and the role of universities as catalysts for business and examined 70 publications. A second part of the study reviewed the environmental activities of 50 universities ranked highly in terms of their environmental credentials or their environmental science courses. The results are presented and then discussed in terms of how universities can affect material flows, promote sustainability outside of the formal curriculum, and act as catalysts with business. The economic significance of universities provides an appreciable demand for circular products and services. Universities should develop "hidden curriculum" plans to promote improved environmental behaviours of staff and students. Universities can also catalyse a circular economy by working with business to improve eco-effectiveness as well as eco-efficiency. For example, projects should extend the focus from decreasing carbon footprint to achieving carbon positivity, from improving water efficiency to treating wastewater, and from recycling to reverse logistics for repurposing. Pilot projects arising from such work could provide valuable research bases and consultancy opportunities.
\end{abstract}

Keywords: circular economy; hidden curriculum; university estate; material flow; environmental management

\section{Introduction}

The dominant economic system for many industries is an unsustainable linear process of take, make, use, and dispose [1]. In addition, the process of extraction, transformation, and disposal of materials is challenged by volatile prices for raw materials due to real or perceived scarcity [2]. Many current business models also result in products that have no end of use value or incur a financial or environmental cost. 
Improved eco-efficiency is one way to address the negative environmental effects of the linear economy, through approaches such as the use of the waste hierarchy or the 3Rs of reduce, reuse and recycle. These approaches can reduce the extent of environmental damage and provide additional income streams for businesses. However, the overall process can still cause, albeit at a lower level, resource degradation and environmental damage through, for example, the use of toxic chemicals [3].

A focus on initiating positive activities, in addition to creating less harm, is captured in the term eco-effectiveness. An eco-effectiveness approach includes the identification of a desired positive outcome and then focuses on the development of products and industrial systems to achieve that target [4]. Braungart et al. [5] explain that the goal of eco-effectiveness is not merely to minimise the cradle to grave flow of materials, but to generate new sustainable cyclical cradle to cradle processes that can enhance the quality of resources. They [5] use the analogy of "metabolism" to describe these processes drawing inspiration from the way, for example, organisms in an ecosystem can continually cycle nutrients. The cradle to cradle design framework has also identified that it is useful to separate natural resources (such as wood and food which can be readily and safely re-incorporated in natural ecosystems) from technical resources (such as plastic or metals which can be toxic and damaging in the wrong place).

The focus of this paper is on the promotion of the circular economy paradigm which draws on the ideas of eco-efficiency and eco-effectiveness to provide an alternative to a linear economy approach. In fact, Murray et al. [6] argue that the term circular economy has gained substantial traction primarily because it is a clear antonym to a linear economy. Although there is no single definitive definition of the circular economy, it builds on many of the concepts of eco-efficiency and eco-effectiveness (Table 1). The Chinese government has used the term to describe their approach to address unsustainable production and consumption by drawing on industrial ecology and life cycle assessment [7]. WRAP in the UK [8] uses the term to describe an economy in which we keep resources in use for as long as possible, extract the maximum value from them whilst in use, then recover and regenerate products and materials at the end of each service life. One of the key organisations promoting a circular economy is the Ellen McArthur Foundation [9]. They define a circular economy as an industrial system that is restorative and regenerative by intention and design. They also outline that the circular economy creates four opportunities for value creation through minimising material use (e.g., efficient cycles), maximising material use (e.g., long cycles), having diversified options (e.g., multiple cycles), and the benefits of ensuring uncontaminated material for reuse (e.g., pure cycles). The last point builds on the cradle to cradle approach in that products should be based on homogeneous materials or built for disassembly so that man-made or technical materials can be reused and biological or natural materials can be cascaded.

The circular economy approach also provides opportunities for new business models (such as product leasing, targeted reverse logistics, and remarketing) which recognise the value of the resources embedded within products whilst at the same time offering a better service to the user $[10,11]$. The circular economy approach is also convergent with the broader requirements of sustainable development listed by Hopwood et al. [12], as it promotes better use of finite resources, increases the resilience of the economic system, increases job opportunities [13], and encourages developments in technology and business studies [14]. Companies implementing the circular economy concept can increase profitability by reducing the costs and the cost variability of raw materials. For example, the Ellen MacArthur Foundation [15] forecasts global material savings valued between $\$ 595$ and $\$ 706$ billion per year for fast-moving consumer goods and profits of $\$ 172$ per tonne of food waste from the transition towards a circular economy. 
Table 1. The circular economy approach builds on the concepts of eco-efficiency and eco-effectiveness.

\begin{tabular}{ll}
\hline Approach & Definition \\
\hline \multirow{2}{*}{ Eco-efficiency } & $\begin{array}{l}\text { The delivery of competitively priced goods and services that satisfy human } \\
\text { needs and bring quality of life, while progressively reducing ecological } \\
\text { impacts and resource intensity throughout the life-cycle to a level at least in } \\
\text { line with the Earth's estimated carrying capacity [16]. }\end{array}$ \\
\hline Eco-effectiveness & $\begin{array}{l}\text { Rather than just focusing on minimising harm, eco-effectiveness seeks to } \\
\text { identify the desirable ecological aspects of products and systems (e.g., } \\
\text { enhance the quality of materials) and then defines and implements a strategy } \\
\text { to achieve that target [3,4]. }\end{array}$ \\
\hline Cradle to Cradle & $\begin{array}{l}\text { Cradle to cradle production is an approach of intelligent material pooling to } \\
\text { achieve eco-effectiveness by viewing all material inputs and outputs either as } \\
\text { technical or biological nutrients. Technical nutrients need to be cycled in } \\
\text { different streams to biological nutrients which can be readily reintegrated in } \\
\text { natural ecosystems [5]. }\end{array}$ \\
\hline $\begin{array}{l}\text { The antonym of a traditional linear economy (e.g., take, make, use, dispose), } \\
\text { which aims to be restorative and regenerative by designing for material reuse, } \\
\text { minimising material flows, keeping resources in use for as long as possible, } \\
\text { and regenerating products and materials within each cycle [5,8,9]. }\end{array}$ \\
\hline
\end{tabular}

Universities play a primary role in propelling new frameworks for managing resources and turning them into a reality. However whilst public organisations and private businesses are making progress in introducing circular economy practices, the extent to which education providers are contributing is unclear. Kopnina and Meijers [17] proposed a framework for using circular economy concepts to embed sustainable development in education environments, but the focus of this research was restricted to early formative years only.

A university's direct impacts can include making the local area more dynamic and diverse by increasing employment and creating income and expenditure flows. It also indirectly impacts local areas by generally upgrading human resources and attracting business in education-related activities [18-20]. One economic assessment found that the university sector accounts for $2.7 \%$ of all UK employment and generates $2.8 \%$ of its GDP based on both on and off campus expenditure [21]. This gives universities the potential to play a key role in the local and regional uptake of circular economy approaches.

Various studies have examined how universities can support sustainable development through formal learning outcomes. Khalili et al. [22] conducted a study to determine how education could develop capabilities for sustainable development and cleaner production. It explored the requirements for the creation of academic programmes in various areas of knowledge that would support national sustainable development goals. In a separate study, Barth [23] highlighted how student-led change from formal and informal learning, sustainability in campus operations, and branding the 'green university' were key factors for embedding sustainability in education. However few studies have focused on the "hidden curriculum" and the role that universities, as part of the local economy, can assume in implementing the sustainability practices they teach. The hidden curriculum is defined as the difference between the actual learning and the curriculum-based learning in the personal student experience within an educational facility [24-26].

There is also relatively little literature on the role of specific circular economy approaches in university estate management; most of the literature focuses on the role of university estates in reducing environmental impacts. The aim of this paper is therefore to detail, analyse, and critique the contribution that universities can bring to the circular economy by addressing three gaps in the literature. The approach used was to undertake a rapid evidence appraisal, a review of material from selected universities, and the results are then examined in relation to three research questions: 
1. What are the material flow transformations that a university estate can develop within the context of the local circular economy?

2. How can a university effectively use and train human resources outside of the formal curriculum?

3. How can a university catalyse circular economy activities in industry?

\section{Materials and Methods}

\subsection{Rapid Evidence Assessment}

In order to bridge research gaps and address the aim of this paper, a question-led, rapid evidence assessment (REA) was conducted. The approach allows the efficient synthesis of evidence and critical assessment of available research in a subject area by focusing on a relatively narrow topic area $[27,28]$. Unlike some systematic reviews, a REA can pre-specify criteria (e.g., only peer-reviewed) for what evidence may be included. The approach is considered more efficient than traditional systematic reviews by limiting the breadth or depth of the process whilst maintaining the same level of quality criteria in assessing evidence $[29,30]$. In this study, the initial scope of the study focused on the interactions between university estate management practice and circular economy theory (Figure 1).

The primary literature chosen to create a broad framework for performing a REA was Thomashow's The Nine Principles for a Sustainable Campus [31] and the factors highlighted by Barth [23], since it focuses on practical experience and academic research. The framework included the content prepared by the Ellen MacArthur Foundation in the form of their "Towards the Circular Economy" reports [9,15,32] and "A New Dynamic: Effective Business in a Circular Economy" [33] to discover the aspects of university management overlapping with the circular economy topics. This initial analysis identified six themes including "campus sustainability", "the hidden curriculum", and "environmental governance". The themes of "the local impact of universities" and "university material flows" focused on the role of universities both as education institutions and economic entities. Finally the operation of "the business in a circular economy" was assessed in terms of its importance towards the university sector and wider society (Figure 1).

Using a series of keywords related to the six themes (Figure 1), the academic search engine Scopus was used to identify 150 pieces of relevant literature. These were then reduced to 70 studies by only including (i) papers appearing in journals with an impact factor cited by the Web of Science, (ii) books receiving a high level of citation on Google Scholar, and (iii) publications relevant to the topic of study. The initial lessons derived from these publications are reported in the initial section of the results.

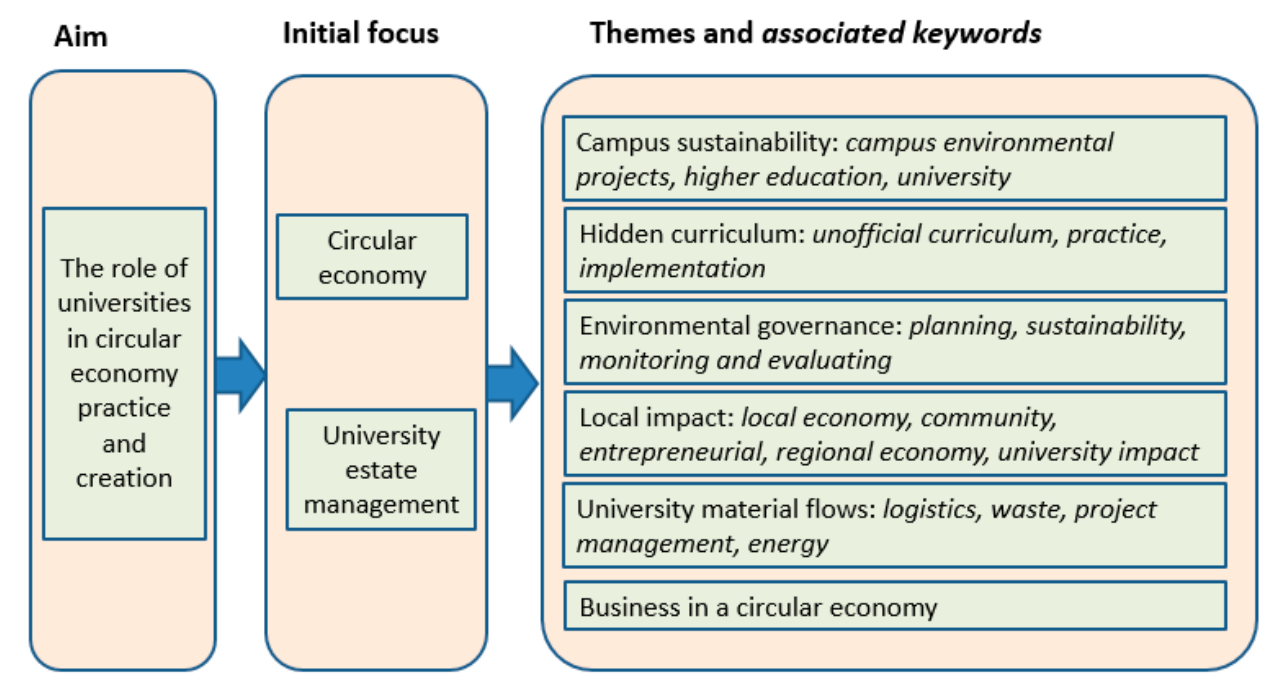

Figure 1. The aim of the rapid evidence assessment, the initial focus, the six identified themes, and choice of identified keywords for the literature review. 


\subsection{Engagement of Universities with the Circular Economy}

Following the implementation of REA, the research set out to gauge how universities practically engage in the circular economy at an operational level. The databases of two global ranking systems were used to understand university environmental practice in sector-leading educational institutions. The UI GreenMetric ${ }^{\circledR}$ [34] was the first global ranking of the sustainable behaviour of universities [35] and was chosen for being the most complete and up to date list that was publicly available. QS๑ Top Universities@ [36] details the global top universities for a range of subjects. Although there are other global rankings (e.g., Shanghai Rankings and Times Higher Education); the QS@ list was chosen as it allowed a specific focus on "environmental science".

We started by identifying the top global universities in environmental performance according to the UI GreenMetric ${ }^{\circledR}$ from 2013 [34], and the top global universities teaching environmental science according to QS๑ Top Universities in 2013 [36]. In order to identify the relationships between a high ranking for environmental performance and a high ranking for teaching, we reviewed the reported environmental activity of the six universities that appeared in the top 50 of both lists. We then explored the reported activity of another 10 universities placed in the top 50 of one list who appeared in the second list, and lastly the remaining universities in the top 25 of either list. This yielded a total of 50 universities, following the elimination of three universities (Chulalongkorn, Kyoto, and Stockholm) due to lack of available information in English. The list of universities and the reported activities reviewed are provided in the Appendix A.

\section{Results}

\subsection{Rapid Evidence Assessment}

The results from the REA of the interaction between universities and support for a circular economy results can be explained in terms of social benefits, the need to monitor assets and flows of energy and materials, the importance of management, the delivery of knowledge, and financial support for innovation. These results are discussed in turn.

The evidence gathered in the REA highlighted that tackling university sustainability must include social, economic, and environmental considerations [37]. On the social side, the literature suggests that high standards for staff and students' physical and mental well-being should be reflected in university strategy and action [31,38]. It is further suggested that empowering a heightened understanding of individual and university impacts on the environment by implementing a 'good-living campus' could cause a more optimistic outlook and foster holistic approaches to environmental problem-solving [31,37,39,40].

It is argued that a circular economy approach requires universities to recognise and start monitoring all assets-natural, financial, social, and intellectual-their use, appreciation or depreciation, and their impacts $[15,27,31,41-43]$. One method of enabling this is the 'input-output' method proposed by $\mathrm{Li}$ [44] and Fry et al. [45] which can capture processes and impacts across entire supply-chain networks underlying, in this case, the operations of a university. Input-output techniques can reveal influences and impacts that lie hidden in distant upstream supply-chain segments, and are thus usually not clear and/or accessible to decision makers, as demonstrated in an institutional footprint study at the University of Sydney, Australia [46]. The impact of particular products can be assessed through life cycle assessments. However, strategists should be mindful of potential rebound effects and a whole system approach should be adopted to mitigate against undesirable consequences of implementing circular economy actions [47].

Energy is one of the most important flows affected by universities. The Carbon Trust [48] reports that two-thirds of all energy consumed by the higher education sector is produced from fossil fuels, largely required for heating and lighting; this compares with UK fossil fuel dependency of about $87 \%$ as of 2012 [49]. Funding sources such as the Revolving Green Fund [50] can help in the transition away from fossil fuels. For example, it has funded the biomass boiler used to power heaters at Cranfield 
University and the refurbishment of a small-scale hydropower facility at the University of Chester. While being individually small, these financially-viable solutions help progress the sector. Another similar programme in the UK is the HEFCE small-scale energy efficiency programme which supports projects with a mean payback period of less than 6.5 years; the mean for successful projects has been 4.5 years [51]. Lighting and heating comprise $80 \%$ of energy use in higher education institutions, so monitoring, infrastructure improvements, renewable heat improvements, and feed-in-tariffs could all play a role, and the government can provide subsidies for selected projects associated with businesses in the UK [52-55].

University management can also affect the flow of materials on campus, in particular in the areas of estate management and service provision [56]. In terms of procurement, incentives for good environmental performance by suppliers needs to be translated from vision to investment throughout the value chain [57]. Supplier dependent firms that invest in procurement partners can especially increase bargaining power, improve relationships and drive down costs [58-60]. Two focus areas in terms of sustainable food sourcing are working with multiple stakeholders to offer choice and benefits, and overcoming the lack of distribution networks [61]. Incentivising local and sustainable food chains, on campus and within the community, can promote healthy lifestyles and diets amongst students [31]. Involving student organisations can promote uptake and coherent behaviour beyond the university's grounds $[31,43,62]$. In short, the development of a circular economy approach to food systems is reported to require communication, engagement, and implementation at all levels [15].

The management of innovations can also be important. Environmental management systems, like ISO 14001, that focus on resource conservation and waste reduction have helped to ensure that $88 \%$ of UK universities had recycling schemes in place by 2007 . However, there were substantially lower proportions of universities who had reuse and composting schemes in place $(57 \%$ and $33 \%$ respectively) [63-65]. It is a requirement of environmental management systems that managers commit to continual improvement of environmental standards including recycling, reuse and refurbishment [66]. However, as discussed in Section 1, there is a risk that the emphasis is placed on doing things that are simply 'less bad', rather than delivering positive benefits. Ghosh et al. [67] report that when undertaking sustainability projects it is helpful to clearly distinguish between the creation of the vision and implementation. One common approach is that a project management team first plans and details all specific projects, and the planned projects are then progressed by implementation teams. Monitoring and feedback loops between them will improve the effectiveness of integration and quality of delivery, abating future project risks, and increasing economic viability $[68,69]$. For breakthrough projects, such as circular economy buildings and products, decision-making also needs to include lateral stakeholders, especially users, to decrease adoption risks [70-73].

As a university's main role is in accreditation and transformation of knowledge into innovation, it is desirable that universities engage individual students in the process $[56,73,74]$. Even old buildings that are not up to sustainability standards can provide a useful learning experience [75], and they can provide platforms to demonstrate the feasibility of curriculum content, and student engagement in the process can further enhance learning [40]. An important responsibility for the hidden curriculum lies with the teaching staff, as they create the context and meaning of the field of study, shaping the information to transmit its importance and maturity [76]. Even so, the students' perception of the staff, the learning environment, and the social environment play a considerable role in how the hidden curriculum is received [77]. While the social environment is particularly hard to control, incentivising and communicating extracurricular activities could enhance soft skills and enhance employability $[26,31,78]$. In this aspect, partnerships with companies to either complement or overlap knowledge bases can be beneficial [79].

Lastly, the review highlighted financial mechanisms that appear to support the uptake of circular economy approaches. For example modular budgets [31], which are a part of some university endowments, can provide baseline sums in multiple instalments without needing a detailed budget. The mean value of such budgets across UK universities was about $£ 1.7$ million in 2012-2013 [53]. A 
second approach is a bank loan, which is paid back as the investments results in increased revenue or savings [31,54]. A third approach is a revolving loan based on a fund, where all returns on investment are returned to the fund to be reinvested in relevant projects [54]. These mechanisms are supplemented by government funding [50], as well as public-private financing [55]. With correct planning and environmental goals, circular economy projects could be candidates to receive all three types of funding.

\subsection{Global Implementation of Sustainability Strategies in Universities}

Most of the 50 universities included within the study, and derived from the two selected ranking lists from 2014, had plans focused on energy efficiency (48) and the reduction of carbon dioxide (43) (Figure 2). By contrast, only 23 universities had a climate action plan, with 11 universities seeking to reach carbon neutrality. The great majority of universities (42) detailed waste management plans, including the diversion of waste from landfill through recycling. There were 32 universities seeking to reduce water use, with 12 focused on the positive impacts of recycling wastewater. Approximately half of the universities (27) were generating at least some of their own energy, often with the primary goal of limiting environmental damage and cost savings. Student-led sustainability projects were an underdeveloped area, as only nine universities were providing incentives for such projects.

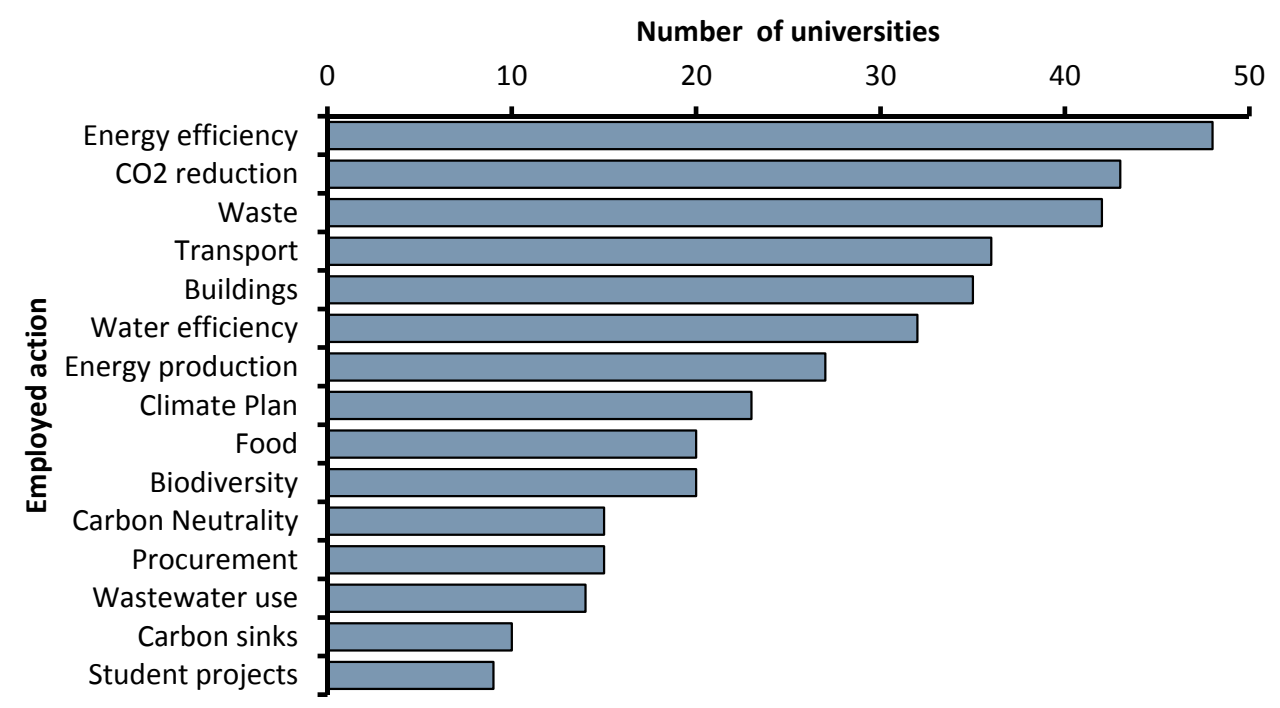

Figure 2. Results from the data analysis of the focal points of environment practice for 50 universities.

The three universities excelling in both environmental education and education had $\mathrm{CO}_{2}$ reduction goals (see Table A2 in Appendix A). Many of those ranking high on the GreenMetric ${ }^{\circledR}$ (see Table A3 in Appendix A) were also aiming towards carbon neutrality. Within the 50 selected universities, 27 universities were producing, or had the intention to produce, energy on campus; 36 had produced transport $\mathrm{CO}_{2}$ reduction methods; while only 15 were focused on carbon sequestration. In total, 30 of the universities studied reported on energy reduction in buildings, 20 had considered sustainable food policies, and 15 had taken a holistic approach for sustainable procurement.

As indicated by the REA, a sustainability mindset can bring positive action and can help people understand how environmental and business practice can improve resource optimisation. The sample provided examples of where a focus on costs and/or resources has led to solutions that are compatible with a circular economy. The grey water harvesting solutions of the Universities of Ottawa [80] and Nottingham [81] are examples that take the full lifecycle of water into consideration. The re:centre building at the University of Bradford [82] is an exemplary demonstration of where a sustainable 
lifecycle has been planned at a university. The building includes a material bank that can allow a circular flow of resources.

The ranking of universities in terms of the reputation of their environmental courses (according to QS(C) as of 2013) was not necessarily consistent with their environmental performance. This could be because older universities (which often have more highly-rated courses) may be responsible for older and more inefficient infrastructures, high costs of refurbishment, and a stronger division between education and estate management. By contrast, universities highlighted in the GreenMetric ${ }^{\circledR}$ list seem to understand the advantages inherent in cost and resource savings. They also appeared to make good use of new funding mechanisms, and made productive use of students and the estate to co-create environmental benefits.

\section{Discussion}

Having completed the REA and an assessment of the activities of universities with highly ranked environmental credentials and/or courses, it becomes pertinent to identify potential ways forward. This is done in relation to how a university can address the following three objectives: (i) to develop material flow transformations, (ii) to effectively use and train people outside the formal curriculum, and (iii) to catalyse circular economy activities in industry (Figure 3).

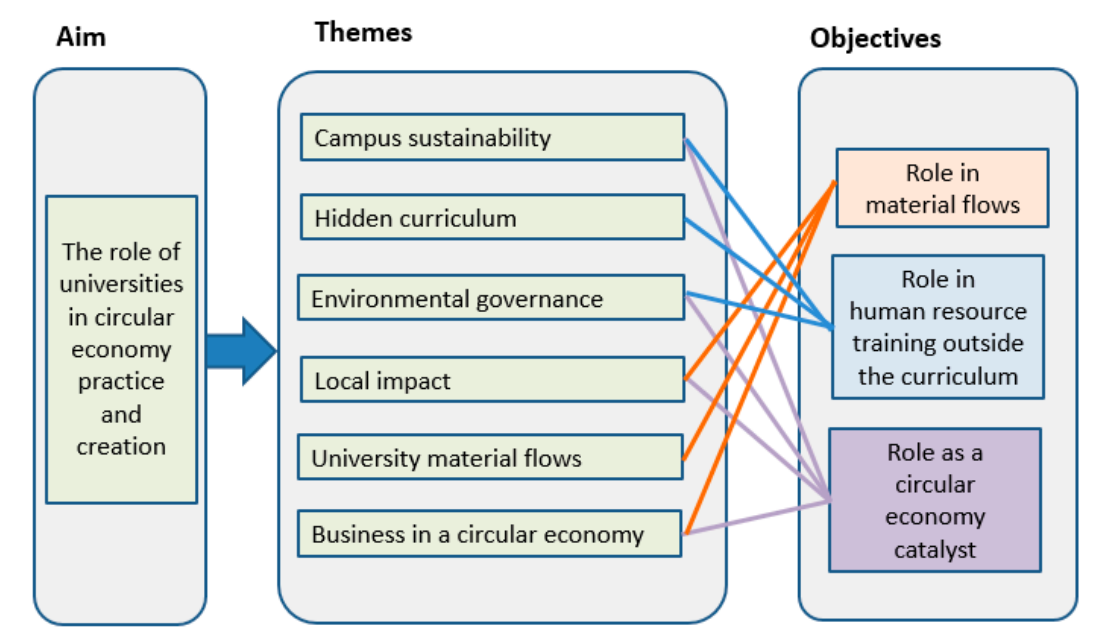

Figure 3. The results from the six themes of the rapid evidence assessment feed into three research objectives.

\subsection{The Role of a University in Material Cycles}

Universities seeking circular material flows need to address procurement and waste management across the entire value chain. This can be policy and target-driven or driven through in-depth conversations with suppliers, partners, and contractors. The former top-down approach can create more clarity and direction with the university being the end user in the system, however the latter allows more inclusive solutions and the co-designing of the standards. Discussions with stakeholders could help ensure that purchased products were designed for disassembly and with non-toxic materials. This could be supported by policies for major reductions in the amount of material sent to landfill, as well as ensuring cleaner streams for upcycling. Service and repair contracts can be used to create reverse logistic flows which provide incentives for the re-use of products or services. Such a holistic approach would allow various material cycles without loss of quality.

Important areas for focus include food, energy, and water use. Biological and food waste can be used within composting and anaerobic digestion projects to promote the reintegration of waste streams. Involving all relevant stakeholders on campus is recommended to match behaviour with ways of maximising the value of the food waste. Such comprehensive reverse logistics would also 
help set expectations for any new partners or tenants. Circular economy approaches to lighting and heating include the use of renewable energy. Circular economy approaches to water use include wastewater treatment, grey water harvesting, and water efficiency solutions such as 'smart' facilities (i.e., automated taps and smart flushing in toilets). Using these would ensure some autonomy, while reducing bills and decreasing losses.

\subsection{Human Resource Development outside of the Formal Curriculum'}

Universities can enhance their capital by investing in the right assets [55], and providing training grounds in sustainable development where future leaders can become environmentally conscious. This should include both a focus on eco-efficiency and eco-effective transformational actions that are 'good' for the environment. Education is needed about the benefits of recycling, the greater returns associated with re-use, and the importance of biological flows. In order to achieve this, universities need to embed local development in their strategies and to combine on-campus projects with a robust curriculum and community action. There is also a need to educate managers, staff and students on the different approaches to sustainable development and their outcomes [74,80,83,84].

To understand the impact of universities in preparing their students for a circular economy, the role students will play in a university circular economy must also be understood. Bartolomeo et al., [85] argue that a lack of understanding about life cycle costs is a barrier to sustainable development, which stops businesses and consumers from seeing the benefits of circular products. Changes in staff and student behaviour around products and their disposal are also needed in order to complement the efforts of the university estate. Feedback should be provided on sustainability initiatives; as such awareness can increase the willingness to participate in projects. This communication of environmental practices can also be extended to visitors.

The literature underlined the importance of involving students in campus environmental plans, but only 9 out of 50 universities assessed currently do this. This figure needs improving to obtain advantages for student development, employment and well-being. An effective way for universities to promote initiatives that can shape student experience and learning for professional life is to implement a hidden curriculum plan. Such a plan, based on alumni feedback, could frame desired skills and behaviours for future careers, and improve the external image of the university. This plan could incorporate goals for mainstreaming leasing models, where the user of the product need not be the owner [86].

Buildings can provide good tools to increase knowledge about the circular economy. Building standards such as the Building Research Establishment Environmental Assessment Method [87], can be presented as good examples. Explaining circular building operations and lifecycles would help enhance students' expectation of the environmental performance of the built environment. Similarly, recycled, refurbished or repurposed products can be promoted in a positive way to encourage acceptance. However if done incorrectly, surrounding students with remade goods could be seen as an imposition rather than a positive choice.

A revolving fund for students and researchers to start their own projects based on a circular economy rationale, could serve as an incubator for sustainable enterprises. Repairing facilities for goods such as electronic items could motivate students. This could provide an area for small repairs to be performed by students for students, supported by tools such as iFixit ${ }^{\circledR}$ [88], or for student hall procurement. Student participation would be encouraged by the prospect of a new source of revenue. This would enable students to have a positive impact on campus services, as well as enhance skill-sets by preparing them for management, visioning, prototyping, and leadership with a circular outlook.

Finally, the hidden curriculum plan should also tackle campus life in a healthy environment that fosters good behaviours to enhance biological cycles. As it was found that quality of life and physical and mental health are important parts of a sustainable campus, increasing healthy food offerings and easy daily exercise options would be beneficial. 


\subsection{The Role of a University in Catalysing the Circular Economy}

The third objective of the work was to examine how a university can catalyse circular economy activities in industry. Collaborations between businesses and universities to promote circular economy activities can be encouraged by third organisations and funding schemes. For example the CE100 Annual Summit organized by the Ellen MacArthur Foundation brings together commercial companies, students, and universities [89]. The UK Government [90] and the European Union [91] also have funding schemes to enable universities and business to work together to create innovations for the circular economy.

At a local level, universities can also start partnerships with local businesses that would enable benefits to be shared and two-way support with implementation and financing. Local circular partnerships can be mutually-beneficial cutting material costs or providing a new income flow. A holistic approach could be needed to start such intra-partner investment in order to identify the long-term benefits that can enable investments to be recouped through improved service provision, returns on investment, and savings. Again, funding mechanisms can support such initiatives, such as the revolving green fund of the Higher Education Funding Council for England (HEFCE) which support circular projects, such as combined heat and power systems [50] that mobilise local economies. The need for holistic thinking is also needed in the construction or refurbishment of buildings. Cost-benefit analyses of buildings' lifecycles become crucial for circular economy infrastructure. However, building upgrades are often only sought if they show a positive net margin. With the context of a circular economy, buildings should be constructed with the aim of reducing energy consumption as well as planning for the disassembly of materials in the long term.

A university can be a key local, regional, or national partner for research and development of practical solutions that enhance a circular economy. It can leverage funding for the creation of new products, develop business models to fit in reverse operations, and influence user behaviour. It can contribute to increased use and retention of biological nutrients to support farming and forestry sectors, and it can advance technology to support transition. Such changes in the management of the waste streams in campuses and university buildings requires planning, and users must be thoroughly informed of waste disposal procedures.

The analysis of ranked universities showed that whilst there was significant evidence of universities undertaking activities to reduce their overall environmental impact, the majority of initiatives focused on energy and resource efficiency and/or reduction. Further initiatives are needed to encourage universities to develop an eco-effective mindset and to invest in those circular initiatives that could result in positive socio- and environmental outcomes.

If universities are used as pilot testing grounds for sustainable innovations, then research to enable data gathering, analysis, and reporting is needed to enable the effective up-scaling of the results. There could also be useful research in user behaviour and the identification of pathways to foster the relationship between service provider and user should build on best practices from the disciplines of psychology and business management. Studies into how such pilots affect university educational performance and student experience could further support the justification of such research.

\subsection{Limitations}

This analysis of the activities of the 50 universities reviewed in this study was completed in 2014, and largely based on reports produced in 2013. Although, universities have continued to advance their environmental sustainability, this study still provides a useful baseline for further analyses. It should also be noted that there are limitations on the rankings used to identify the 50 selected universities. The GreenMetric and QS lists are not definitive and additionally environmental science is not taught at all universities therefore the research presented reflects sustainable practise at a pre-defined group of universities. Further research is required to assess whether the findings of the research can be generalised across the higher education sector. 


\section{Conclusions}

The vision of a circular economy is that key non-renewable resources should be used sustainably, and this involves different parts of the university working together and with others in a symbiotic way. There are multiple areas in which universities can target operations and research, complemented by suppliers from multiple sectors and government institutions. This paper presents a novel investigation of how universities are embedding circular economy approaches. It has focused on universities' material cycles, human resources development outside of the curriculum, and the university's role as a catalyst for circular economy approaches in industry. The three key conclusions and associated recommendations are:

(i) Universities need to progress their sustainability plans if they are to fully contribute to a circular economy. This is particularly the case for the strategic and environmental plans that shape the operation of universities. The use of life cycle assessments can help universities quantify the environmental impacts of different circular economy strategies. Working groups should be created that can identify, enable, and organise finance for potential improvements in material flows. Projects must shift their focus to address eco-effectiveness as well as eco-efficiency, for example from decreasing a carbon footprint to achieving carbon negativity on campus, from increasing water efficiency to treating wastewater, and from increasing recycling to implementing symbiosis and reverse logistics.

(ii) Many universities are using a circular economy as a focus for both teaching and research. However the development of a hidden curriculum plan would further enhance sustainability strategies and learning in practice by encouraging sustainable consumption and behaviour. Promoting new circular economy enterprises on campus could enhance student skills through involvement and portray sustainable commerce as a realistic business opportunity.

(iii) There are real synergies to be gained from universities engaging with industry partners already pursuing sustainability strategies. The potential rewards include reduced long-term costs for the university, enhanced reputations, and funding opportunities.

In summary, the changes in design, manufacturing and services associated with a circular economy create resource, research and business opportunities. Agile universities can play a key role in helping to promote circular economy approaches by engaging their students and being a key partner with both public and private organisations. This paper highlights how universities have the power to alter procurement policies and thereby material and product flows, the demand power to scale products and services, and the influence to disseminate it through their graduates, local communities and wider society.

Author Contributions: Conceptualization, B.T.N., S.J.T.P., and P.J.B.; Formal analysis, B.T.N.; Methodology, B.T.N.; Resources, G.E.; Supervision, S.J.T.P. and P.J.B.; Validation, G.E. and I.C.d.I.R.; Writing—review \& editing, I.C.d.l.R., F.C., and P.J.B.

Funding: This research was funded through the Facilities professional services unit of Cranfield University for the University's Board for Energy and the Environment. Cranfield's commitment to environmental sustainability and the hidden curriculum is available here: https:/ /www.cranfield.ac.uk/about/environmental-credentials.

Conflicts of Interest: The authors declare no conflict of interest. 


\section{Appendix A}

Table A1. Universities that rank in the top 50 of both GreenMetric ${ }^{\circledR}$ (2013) and QSC list for environmental science (2013).

\begin{tabular}{|c|c|c|c|}
\hline University & $\begin{array}{l}\text { Green } \\
\text { Metric }^{\circledR} \\
(2013)\end{array}$ & $\begin{array}{r}\text { QS@ } \\
(2013)\end{array}$ & Activities \\
\hline $\begin{array}{l}\text { University of } \\
\text { California } \\
\text { Davis }\end{array}$ & 9 & 12 & $\begin{array}{l}\text { Improving buildings (energy efficiency, water, waste), } \\
\text { imbedding in new build, reduce energy use, replacing fossil } \\
\text { fuels for renewables, travel emission reductions, carbon } \\
\text { sequestration. }\end{array}$ \\
\hline $\begin{array}{l}\text { University of } \\
\text { California, Los } \\
\text { Angeles }\end{array}$ & 11 & 33 & $\begin{array}{l}\text { Energy efficiency in existing buildings and new, expansion of } \\
\text { renewable energy portfolio, cap-and-trade, fleet } \\
\text { transformation off fossil fuels, sustainable food procurement, } \\
\text { water efficiency. }\end{array}$ \\
\hline $\begin{array}{l}\text { University of } \\
\text { California, } \\
\text { Berkeley }\end{array}$ & 14 & 1 & $\begin{array}{l}\text { New build minimising energy and water consumption, and } \\
\text { involving sustainable design principles including material } \\
\text { fully life costs. Water use minimisation driven by residence } \\
\text { halls, procurement of environmentally friendly products, } \\
\text { sustainable food purchases at } 28 \% \text {, fuel used by commuters } \\
\text { and campus fleet reduced by } 50 \% \text {. }\end{array}$ \\
\hline $\begin{array}{l}\text { University of } \\
\text { Melbourne }\end{array}$ & 18 & 18 & $\begin{array}{l}\text { New buildings all qualify for } 5 \text {-star green design ratings. } 24 \% \\
\text { reduction in energy; } 49 \% \text { reduction in net energy related } \\
\text { carbon emissions; } 38 \% \text { reduction in water usage; } 41 \% \\
\text { recycling of waste; and Development of a Green IT program. }\end{array}$ \\
\hline $\begin{array}{l}\text { University of } \\
\text { Washington }\end{array}$ & 28 & 48 & $\begin{array}{l}\text { Student lead projects through Campus Sustainability Fund } \\
\text { with awards between } \$ 250 \text { and } \$ 100,124.8 \% . \mathrm{CO}_{2} \text { reduction } \\
\text { achieved, commuters driving alone to } 19 \% .59 \% \text { of sustainable } \\
\text { foods, waste diverted from landfill at } 58 \% . \$ 13.1 \mathrm{~m} \text { in utility } \\
\text { savings, cooking oil to biodiesel conversion. }\end{array}$ \\
\hline $\begin{array}{l}\text { National } \\
\text { University of } \\
\text { Singapore }\end{array}$ & 44 & 19 & $\begin{array}{l}\text { Reduced plastic bag use by } 80 \% \text { by charging for them, } \\
\text { increased recycling streams, } 13 \text { buildings awarded for } \\
\text { environmental performance. } 70 \% \text { of staff and } 75 \% \text { of students } \\
\text { on board with environmental practices, including inter-hall } \\
\text { competitions for waste reduction. }\end{array}$ \\
\hline
\end{tabular}

Table A2. Universities that feature in the top 50 of the QS@ list (2013) and also feature anywhere on the GreenMetric ${ }^{\circledR}$ list (2013).

\begin{tabular}{cccl}
\hline University & $\begin{array}{c}\text { Green } \\
\text { Metric }^{\circledR}\end{array}$ & QS $\odot ~$ & \multicolumn{1}{c}{ Activities } \\
\hline $\begin{array}{c}\text { Georgia Institute of } \\
\text { Technology }\end{array}$ & 64 & 44 & $\begin{array}{l}\text { 9 LEED certified buildings; retrofitting 64 campus buildings } \\
\text { with energy and water efficiency; 46 more buildings to reduce } \\
\text { energy use by 15\%; 500kW of solar PV on campus in 2012; a } \\
\text { geothermal heat pump. }\end{array}$ \\
\hline Kyoto University & 206 & 45 & $\begin{array}{l}\text { Energy reduction and yearly environmental reports and a } \\
\text { long term plan. }\end{array}$ \\
\hline $\begin{array}{c}\text { Stockholm } \\
\text { University }\end{array}$ & 190 & 47 & $\begin{array}{l}\text { Information available through further contact, no translated } \\
\text { information available. }\end{array}$ \\
\hline
\end{tabular}


Table A3. Universities that featured in the top 50 of the GreenMetric ${ }^{\circledR}$ list (2013) and on the QS( (2013) list.

\begin{tabular}{|c|c|c|c|}
\hline University & $\begin{array}{l}\text { Green } \\
\text { Metric }^{\circledR}\end{array}$ & QS@ & Activities \\
\hline $\begin{array}{l}\text { University of } \\
\text { Nottingham }\end{array}$ & 1 & $101-150$ & $\begin{array}{l}\text { Improvements in recycling rates from } 4 \% \text { to } 29 \% \text { in (clean } \\
\text { recycling streams) and } 85 \% \text { by } 2012 \text { (including separation by } \\
\text { waste contractor). Water savings by urinal controls, leakage } \\
\text { detection work, and grey water harvesting. }\end{array}$ \\
\hline $\begin{array}{l}\text { University College } \\
\text { Cork National } \\
\text { University of } \\
\text { Ireland }\end{array}$ & 2 & $151-200$ & $\begin{array}{l}\text { Achieved an increase in the campus recycling rate from } 21 \% \\
\text { to } 75 \% \text { in } 2013, \text { a } 9 \% \text { decrease in total energy consumption. } \\
\text { Staff choosing to cycle to work to } 12 \% \text { in } 2012 \text {; a saving of } \\
€ 1,000,000 \text { on waste costs over the last } 6 \text { years; a saving of over } \\
750,000 \text { cubic metres of water saved since } 2007 \text {. }\end{array}$ \\
\hline $\begin{array}{l}\text { University of North } \\
\text { Carolina, Chapel } \\
\text { Hill }\end{array}$ & 8 & $51-100$ & $\begin{array}{l}\text { Green roofs, also used as water filters and buffers; } 12 \% \\
\text { reduction in building related GHG emissions; } 33 \% \text { reduction } \\
\text { in energy since 2003; all new buildings have LEED Gold } \\
\text { certification; 23\% less petroleum use since 2005; } 42 \% \text { of waste } \\
\text { diverted from landfill; } 25 \% \text { of local or sustainable food in } \\
\text { dining services, and } 13 \% \text { also organic. }\end{array}$ \\
\hline $\begin{array}{c}\text { Universiti Putra } \\
\text { Malaysia }\end{array}$ & 16 & $101-150$ & $\begin{array}{l}\text { Environmental conservation through use of local species; } \\
\text { promotes the use of bicycles and biodegradable materials on } \\
\text { campus; certified ISO 14001: } 2004 \text { and must continuously } \\
\text { improve environmental practice because of it; amongst many } \\
\text { other solutions. }\end{array}$ \\
\hline $\begin{array}{l}\text { University of } \\
\text { Ottawa }\end{array}$ & 25 & $151-200$ & $\begin{array}{l}\text { Community gardens establishment; Fair Trade campus; } \\
\text { furniture and goods reuse programmes; campus wide bicycle } \\
\text { lanes with repair stations on campus; improving lighting on } \\
\text { campus with sensors; implementing waterless urinals; } \\
\text { eliminating bottled water; increasing grey-water capacity; } 51 \% \\
\text { waste diverted from landfill (2011); responsible irrigation; use } \\
\text { of drought resistant native plants; carpooling, discounted } \\
\text { transit passes, bicycle incentives, and shuttles. }\end{array}$ \\
\hline $\begin{array}{l}\text { University of } \\
\text { Massachusetts, } \\
\text { Amherst }\end{array}$ & 37 & $101-150$ & $\begin{array}{l}\text { Campus permaculture initiatives; Sustainability Innovation \& } \\
\text { Engagement Fund; } 27 \% \mathrm{CO}_{2} \text { reductions since } 2004 ; \text { central } \\
\text { heating plant (mostly burning natural gas) reduces } 30 \% \text { of } \\
\text { GHG emissions; incentives for electrical car buying and } \\
\text { charging stations; bicycle and car sharing incentives; } \\
\text { composting widespread; reclaimed water; low flow water } \\
\text { fixtures widespread; single stream waste recycling. }\end{array}$ \\
\hline $\begin{array}{l}\text { Chulalongkorn } \\
\text { University }\end{array}$ & 50 & $101-150$ & Activity exists, but non-discernible, not easy to find. \\
\hline
\end{tabular}

Table A4. Top 25 QS@ ranked universities (2013) in environmental science programmes, which did not rank on the GreenMetric ${ }^{\circledR}$ (2013).

\begin{tabular}{cc}
\hline University & QS $\odot ~$ \\
\hline Stanford University & 2 \\
Massachusetts Institute of Technology & 3 \\
Harvard University & 4 \\
ETH Zurich & 5 \\
University of Oxford & 6 \\
University of Cambridge & 7 \\
Imperial College London & 8 \\
The University of Queensland & 9 \\
Wageningen University & 10 \\
\hline
\end{tabular}


Table A4. Cont.

\begin{tabular}{cc}
\hline University & QS $\odot ~$ \\
\hline University of Michigan & 11 \\
Yale University & 13 \\
University of Wisconsin-Madison & 14 \\
Cornell University & 15 \\
University of British Columbia & 16 \\
Delft University of Technology & 17 \\
Tsinghua University & 19 \\
University of Toronto & 21 \\
University of Sheffield & 22 \\
Australian National University & 23 \\
University of Colorado Boulder & 24 \\
The University of Tokyo & 25 \\
\hline
\end{tabular}

Table A5. Top 25 GeenMetric $^{\circledR}$ ranked universities (2013), which do not rank on the QSC ranking (2013) of top environmental science programmes.

\begin{tabular}{cc}
\hline University & Green $^{\text {Metric }}{ }^{\circledR}$ \\
\hline Northeastern University & 3 \\
University of Bradford & 4 \\
University of Connecticut & 5 \\
Université de Sherbrooke & 6 \\
University of Plymouth & 7 \\
Unith Carolina Agricultural \& Technology State & 10 \\
University & 12 \\
University of Alcalá & 13 \\
University of Bath & 15 \\
University of California, Merced & 17 \\
Bangor University & 19 \\
Linkoping University & 20 \\
University of Sussex & 21 \\
Virginia Commonwealth University & 22 \\
National Taipei University of Technology & 23 \\
Universidad Autónoma de Madrid & 24 \\
\hline
\end{tabular}

Table A6. References for the "published plans of universities" accessed for the study.

ACUPCC Reports (2013). Climate Action Plan for Virginia Commonwealth University.

http:/ /rs.acupcc.org/cap/627/ (accessed on 20 August 2014)

Australian National University (2014). Academic structure.

http:/ / about.anu.edu.au/governance-structure/university-structure/academic-structure/ (accessed on 20 August 2014)

Australian National University (2014). Campus-About ANU.

http: / / about.anu.edu.au/campus (accessed on 20 August 2014)

Australian National University (2014). Sustainability.

http:/ / sustainability.anu.edu.au/ (accessed on 20 August 2014)

Bangor University (2010). Strategic Plan 2010-2015. 1st ed. [ebook] Bangor: Bangor University.

http:/ / www.bangor.ac.uk/stratplan/SP10\%20v6\%20Print\%20version.pdf (accessed on 20 August 2014)

Bangor University (2014). Academic Schools.

http:/ / www.bangor.ac.uk/corporate/informationabout/depts.php\#4 (accessed on 20 August 2014)

Chulalongkorn University (2014). Faculties \& Departments.

http:/ / www.chula.ac.th/en/faculties-and-departments / (accessed on 30 July 2014) 
Table A6. Cont.

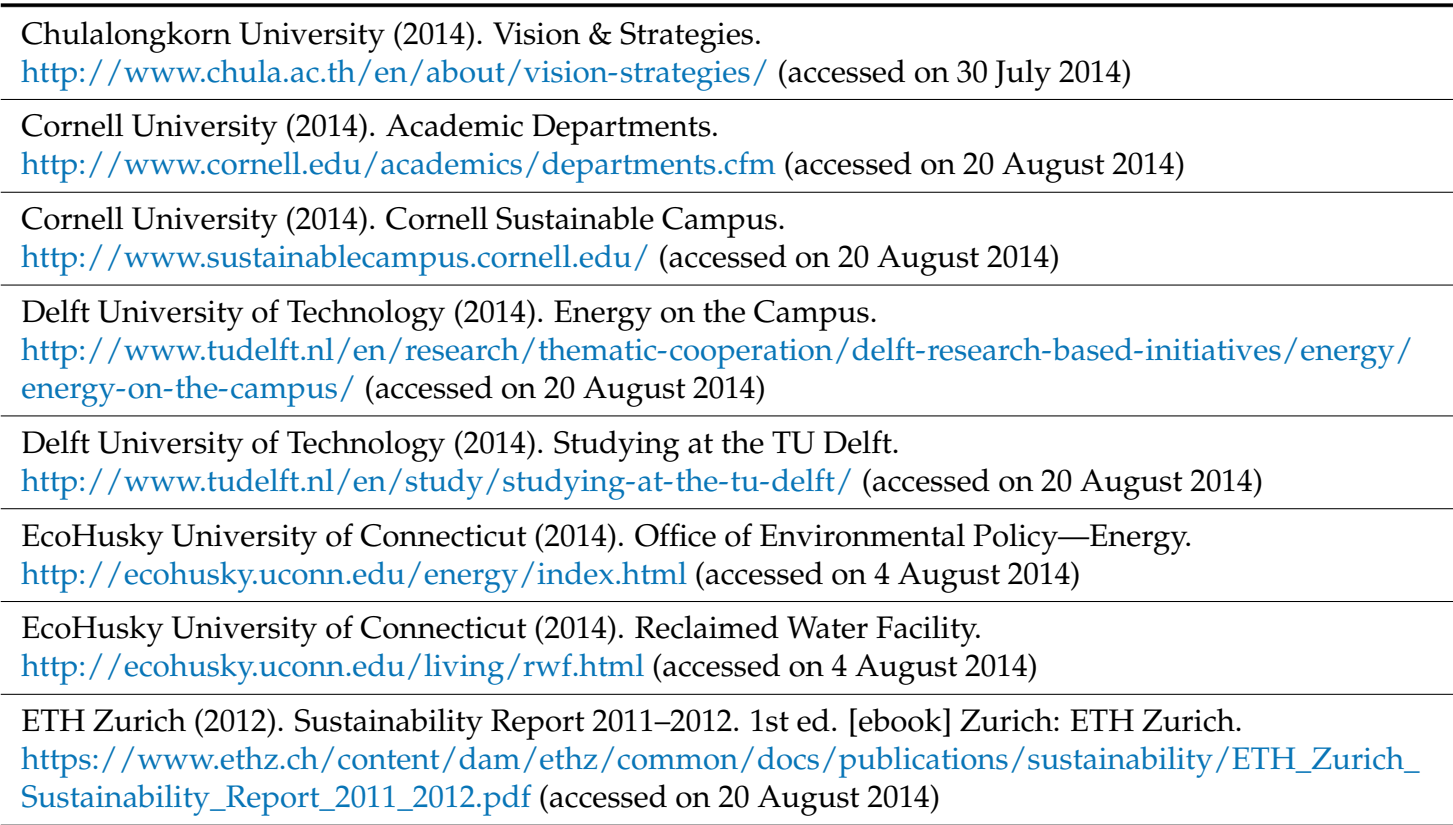

ETH Zurich (2014). Master's degree programmes.

https:/ / www.ethz.ch/en/studies / prospective-masters-degree-students / masters-degree-programmes / masters-degree-programmes-system-oriented-natural-sciences.html (accessed on 20 August 2014)

Ferguson M. (2014). University of Washington: Integrating Sustainability. 1st ed. [ebook] University of Washington.

http:/ / green.uw.edu/sites/default/files/awards/ISCN\%20Presentation\%202014.pdf (accessed on 26 July 2014)

Food Plymouth (2014). Plymouth Food Charter.

http: / / www.foodplymouth.org/?page_id=61 (accessed on 6 August 2014)

Georgia Institute of Technology (2014). Colleges \& Schools.

http:/ / www.gatech.edu/academics/colleges-and-schools (accessed on 30 July 2014)

Harvard (2014). Green Harvard.

http:/ / green.harvard.edu/ (accessed on 20 August 2014)

Harvard (2014). Teaching Areas School of Engineering and Applied Sciences.

http: / / www.seas.harvard.edu/about-seas/teaching-areas (accessed on 20 August 2014)

Imperial College (2014). Energy and Environment.

http:/ / www3.imperial.ac.uk/estatesfacilities/services/energy (accessed on 20 August 2014)

Imperial College (2014). Faculties \& Departments.

http:/ / www3.imperial.ac.uk/a_to_z (accessed on 20 August 2014)

Kinstler M. (2013). Georgia Tech Sustainability Summary. 1st ed. [ebook] Georgia Institute of Technology. http:/ / stewardship.gatech.edu/images /4\%20pg\%20summary\%20January\%202013.pdf (accessed on 30 July 2014)

Kyoto University (2014). Faculties \& Graduate Schools.

http:/ / www.kyoto-u.ac.jp/en/faculties_and_graduate (accessed on 30 July 2014)

Linköping University (2013). Linköping University's environmental objectives for the period 2013-2015.

1st ed. [ebook] Linköping: Linköping University.

http:/ / www.liu.se/insidan/miljo/mal/miljomalsarbetet/1.484440/

LiUenvironmentalobjectivesfortheperiod2013-2015.pdf (accessed on 20 August 2014)

Linköping University (2014). Masters.

http://www.liu.se/utbildning/pabyggnad?l=en (accessed on 20 August 2014)

MIT (2014). Campus Energy Task Force.

http:/ / mitei.mit.edu/campus-energy/campus-energy-task-force (accessed on 20 August 2014) 
Table A6. Cont.

\begin{tabular}{|c|c|}
\hline $\begin{array}{l}\text { MIT (2014). Education. } \\
\text { http://web.mit.edu/education/ (accessed on } 20 \text { August 2014) }\end{array}$ & \\
\hline \multicolumn{2}{|l|}{$\begin{array}{l}\text { MIT (2014). MIT Facilities-Sustainability. } \\
\text { http://web.mit.edu/facilities/environmental/ (accessed on } 20 \text { August 2014) }\end{array}$} \\
\hline \multicolumn{2}{|l|}{$\begin{array}{l}\text { National Taipei University of Technology (2014). Visit Taipei Tech. } \\
\text { http://www-en.ntut.edu.tw / files/13-1128-37134.php (accessed on } 20 \text { August 2014) }\end{array}$} \\
\hline \multicolumn{2}{|c|}{$\begin{array}{l}\text { National Taipei University of Technology (2014). Departments. } \\
\text { http:/ / www-en.ntut.edu.tw / files/13-1128-36997.php (accessed on } 20 \text { August 2014) }\end{array}$} \\
\hline \multicolumn{2}{|c|}{$\begin{array}{l}\text { North Carolina A\&T State University (2014). Energy Services and Sustainability. } \\
\text { http:/ / www.ncat.edu/divisions/business-and-finance/facilities/sustain/ (accessed on } 5 \text { August 2014) }\end{array}$} \\
\hline \multicolumn{2}{|c|}{$\begin{array}{l}\text { North Carolina A\&T State University (2014). Schools \& Colleges. } \\
\text { http:/ / www.ncat.edu/academics/schools-colleges1/index.html (accessed on } 5 \text { August 2014) }\end{array}$} \\
\hline \multicolumn{2}{|c|}{$\begin{array}{l}\text { North Carolina A\&T State University (2014). Sustainability Department. } \\
\text { http:/ / www.ncat.edu/divisions/business-and-finance/facilities/pp/sustain.html (accessed on } \\
5 \text { August 2014) }\end{array}$} \\
\hline \multicolumn{2}{|c|}{$\begin{array}{l}\text { Northeastern University (2010). Sustainable Action Plan: Roadmap towards carbon neutrality. 1st ed. } \\
\text { [ebook] Boston: Northeastern University. } \\
\text { http:/ / rs.acupcc.org/site_media/uploads/cap/551-cap.pdf (accessed on } 4 \text { August 2014) }\end{array}$} \\
\hline \multicolumn{2}{|c|}{$\begin{array}{l}\text { Northeastern University (2014). Departments \& Programs. } \\
\text { http://www.northeastern.edu/neuhome/academics/departments-programs.html (accessed on } \\
3 \text { August 2014) }\end{array}$} \\
\hline \multicolumn{2}{|c|}{$\begin{array}{l}\text { Northeastern University (2014). Sustainability Initiatives. } \\
\text { http://www.northeastern.edu/sustainability / initiatives/index.html (accessed on } 4 \text { August 2014) }\end{array}$} \\
\hline \multicolumn{2}{|l|}{$\begin{array}{l}\text { NU Singapore OES (2014). Office of Environmental Sustainability Homepage. } \\
\text { http:/ / www.nus.edu.sg/oes/index.html (accessed on } 29 \text { July 2014) }\end{array}$} \\
\hline \multicolumn{2}{|c|}{$\begin{array}{l}\text { NU Singapore OES (2014). Sustainability Modules. } \\
\text { http:/ / www.nus.edu.sg/oes/prog/envedu/modules.html (accessed on } 29 \text { July 2014) }\end{array}$} \\
\hline \multicolumn{2}{|c|}{$\begin{array}{l}\text { NU Singapore OES (2014). SustainABLE NUS. } \\
\text { http:/ / www.nus.edu.sg/oes/prog/SustainABLE\%20NUS/SustainABLE\%20NUS.html (accessed on } 29 \\
\text { July 2014) }\end{array}$} \\
\hline \multicolumn{2}{|c|}{$\begin{array}{l}\text { NU Singapore (2014). NUS Singapore University College Degree Courses In Singapore. } \\
\text { http:/ / www.nus.edu.sg/education/academic/faculties-and-schools (accessed on } 29 \text { July 2014) }\end{array}$} \\
\hline \multicolumn{2}{|c|}{$\begin{array}{l}\text { Parker P. (2014). Green on campus. Stockholm University. } \\
\text { http:/ / www.su.se/english/about/green-on-campus-1.726 (accessed on } 30 \text { July 2014) }\end{array}$} \\
\hline \multicolumn{2}{|c|}{$\begin{array}{l}\text { Plymouth University (2014). A sustainable campus. } \\
\text { https://www1.plymouth.ac.uk/sustainability/campus/Pages/sustainablecampus.aspx (accessed on } 6 \\
\text { August 2014) }\end{array}$} \\
\hline \multicolumn{2}{|l|}{$\begin{array}{l}\text { Plymouth University (2014). Courses and Study. } \\
\text { http:/ / www5.plymouth.ac.uk/courses-and-study (accessed on } 6 \text { August 2014) }\end{array}$} \\
\hline \multicolumn{2}{|c|}{$\begin{array}{l}\text { Plymouth University (2014). Plymouth Woodland Project. } \\
\text { http://www1.plymouth.ac.uk/sustainability/woodlandproject/Pages/default.aspx (accessed on } 6 \\
\text { August 2014) }\end{array}$} \\
\hline \multicolumn{2}{|c|}{$\begin{array}{l}\text { Plymouth University (2014). Strategic goals. } \\
\text { http:/ / www1.plymouth.ac.uk/sustainability / Pages / default.aspx (accessed on } 6 \text { August 2014) }\end{array}$} \\
\hline \multicolumn{2}{|l|}{$\begin{array}{l}\text { Stanford University (2014). Departments. } \\
\text { http:/ / www.stanford.edu/academics/ (accessed on } 20 \text { August 2014) }\end{array}$} \\
\hline \multicolumn{2}{|l|}{$\begin{array}{l}\text { Stockholm University (2014). Departments. } \\
\text { http:/ / www.su.se/english/departments (accessed on } 30 \text { July 2014) }\end{array}$} \\
\hline $\begin{array}{l}\text { Sustainable Stanford (2014). What We Are Doing. } \\
\text { http://ssu.stanford.edu/what_we_are_doing (accessed on } 20 \text { August 2014) }\end{array}$ & \\
\hline
\end{tabular}


Table A6. Cont.

The University of British Columbia (2014). Faculties and Schools.

http:/ / www.ubc.ca/our-campuses/vancouver/directories/faculties-schools.html (accessed on 20 August 2014)

The University of British Columbia (2014). Sustainability Plans.

http:/ / sustain.ubc.ca/our-commitment/strategic-plans-policies-reports/sustainability-plans (accessed on 20 August 2014)

The University of Nottingham (2014). Postgraduate Courses.

http:/ / www.nottingham.ac.uk/pgstudy/courses/courses.aspx (accessed on 29 July 2014)

The University of Queensland (2014). Courses and Programs.

http:/ / www.uq.edu.au/study/index.html (accessed on 20 August 2014)

The University of Queensland (2014). Sustainability Website.

http:/ / www.uq.edu.au/sustainability/ (accessed on 20 August 2014)

The University of Tokyo (2014). Admissions and Programs.

http:/ / www.u-tokyo.ac.jp/en/admissions-and-programs/graduate-and-research/index.html\#g002 (accessed on 20 August 2014)

The University of Tokyo (2014). Todai Sustainable Campus Project Website. http:/ / www.tscp.u-tokyo.ac.jp/en/about.html (accessed on 20 August 2014)

The University of York (2014). Departments-Teaching units.

http:/ / www.york.ac.uk/about/departments/teaching/ (accessed on 20 August 2014)

The University of York (2014). Sustainability.

http:/ / www.york.ac.uk/about/sustainability/ (accessed on 20 August 2014)

Tsinghua University (2014). Schools \& Departments.

http:/ / www.tsinghua.edu.cn/publish/newthuen/newthuen_cnt/faculties/faculties-1.html (accessed on 20 August 2014)

UC Berkeley Long Range Development Plan (2014). UC Berkeley 2020 Long Range Development Plan Documents.

http:/ /lrdp.berkeley.edu/ (accessed on 29 July 2014)

UC Berkeley (2014). UC Berkeley Colleges \& schools.

http: / / www.berkeley.edu/academics/school.shtml (accessed on 29 July 2014)

UC Berkley (2014). CalCAP Sustainability.

http:/ / sustainability.berkeley.edu/calcap (accessed on 29 July 2014)

UC Davis Sustainability (2014). UC Davis Sustainable 2nd Century.

http:/ / sustainability.ucdavis.edu/ (accessed on 29 July 2014)

UC Davis Sustainability (2014). UC Davis Sustainable 2nd Century Our Commitment.

http:/ / sustainability.ucdavis.edu/progress/commitment/index.html (accessed on 29 July 2014)

UC Davis (2014). UC Davis Academic departments.

http:/ / www.ucdavis.edu/academics/academic-depts.html (accessed on 29 July 2014)

UC Davis (2014). UC Davis Colleges and Schools.

http:/ / www.ucdavis.edu/academics/index.html\#colleges (accessed on 29 July 2014)

UCB New Century Plan (2014). UCB New Century Plan.

http:/ / www.cp.berkeley.edu/ncp/ (accessed on 29 July 2014)

UCLA Grand Challenges (2014). UCLA Grand Challenges.

http:/ / www.grandchallenges.ucla.edu/ (accessed on 29 July 2014)

UCLA Sustain (2014). UCLA Sustainability.

http:/ / www.sustain.ucla.edu/ (accessed on 29 July 2014)

UCLA Sustain (2014). UCLA Sustainability Our Initiatives.

http: / / www.sustain.ucla.edu/ our-initiatives / (accessed on 29 July 2014)

UCLA (2014). UCLA Departments \& Programs.

http:/ / www.ucla.edu/academics / departments-and-programs (accessed on 29 July 2014)

UMass Amherst Academics (2014). Schools and Colleges.

http:/ / www.umass.edu/gateway/academics/schools-and-colleges (accessed on 30 July 2014) 
Table A6. Cont.

UMass Sustainability (2014). Learn Live Lead - Sustainable UMass.
http: / / www.umass.edu/sustainability / (accessed on 30 July 2014)

UMass Sustainability (2014). Live Sustainably at UMass Amherst.

http:/ / www.umass.edu/sustainability/green-campus (accessed on 30 July 2014)

UN Sustainable Development (2014). Tsinghua University.

http: / / sustainabledevelopment.un.org /index.php?page=view\&type=1006\&menu=1348\&nr=366

(accessed on 20 August 2014)

Universidad Autónoma de Madrid (2014). Facultad de Ciencias.

http:/ / www.uam.es/cs/ContentServer/Ciencias/es/1242669529494/contenidoFinal/Departamento_ de_Ecologia.htm (accessed on 20 August 2014)

Universidad de Alcalá (2014). Centros y departamentos.

http:/ / www.uah.es/centros_departamentos/centros_departamentos.shtm (accessed on 6 August 2014)

Universidad de Alcalá (2014). Compromiso Medioambiental-Energía.

http: / / www.uah.es/sostenibilidad/programas.asp?lista=2 (accessed on 5 August 2014)

Université de Sherbrooke (2014). Gestion des matières résiduelles.

http:/ / www.usherbrooke.ca/developpement-durable/campus/matieres/ (accessed on 5 August 2014)

Université de Sherbrooke (2014). Plan en actions: Plan stratégique 2010-2015.

http:/ / www.usherbrooke.ca/reussir/plan-en-actions/ (accessed on 5 August 2014)

Université de Sherbrooke (2014). Secteurs.

http://www.usherbrooke.ca/premier-cycle/programmes/bac/sec/ (accessed on 5 August 2014)

Universiti Putra Malaysia EMS (2014). Environment Management System (EMS).

http:/ / marcomm.upm.edu.my/green/?page_id=131 (accessed on 30 July 2014)

Universiti Putra Malaysia Green initiatives (2014). Green initiatives.

http: / / marcomm.upm.edu.my / green/?p=208 (accessed on 30 July 2014)

Universiti Putra Malaysia News (2014). Special Mango Grove to Promote Environmental Conservation.

http:/ / www.upm.edu.my/news / details/dusunmanggabi (accessed on 30 July 2014)

Universiti Putra Malaysia (2014). Green@UPM.

http:/ / marcomm.upm.edu.my/green/ (accessed on 30 July 2014)

Universiti Putra Malaysia (2014). Programmes \& Courses.

http:/ / www.upm.edu.my/academic/ProgrammesCourses (accessed on 30 July 2014)

University College Cork Academic (2014). University College Cork Departments.

http:/ / www.ucc.ie/en/academic/ (accessed on 29 July 2014)

University College Cork (2014). Green Success.

http:/ / www.ucc.ie/en/greencampus/greensuccess / (accessed on 29 July 2014)

University College Cork (2014). Recycling \& Waste Buildings and Estates.

http:/ / www.ucc.ie/en/build/environment/recycling/ (accessed on 29 July 2014)

University College Cork (2014). Water-Buildings and Estates.

http:/ / www.ucc.ie/en/build/environment/water/ (accessed on 29 July 2014)

University of Bath (2014). Faculties \& Departments.

http:/ / www.bath.ac.uk/departments/ (accessed on 20 August 2014)

University of Bath (2014). Our values.

http:/ /www.bath.ac.uk/about/values/index.html (accessed on 20 August 2014)

University of Bradford re:centre (2014). Inspirational Building.

http:/ / www.bradford.ac.uk/recentre/about-us/inspirational-building/ (accessed on 5 August 2014)

University of Bradford (2014). Environmental Performance Dashboard.

http://www.bradford.ac.uk/estates/environment/performance/\#d.en.99287 (accessed on 4 August 2014)

University of Bradford (2014). Environmental Strategy.

http:/ / www.bradford.ac.uk/estates/environment/strategy/ (accessed on 4 August 2014)

University of Bradford (2014). Our Courses.

http:/ / www.bradford.ac.uk/study/our-courses/ (accessed on 4 August 2014) 
Table A6. Cont.

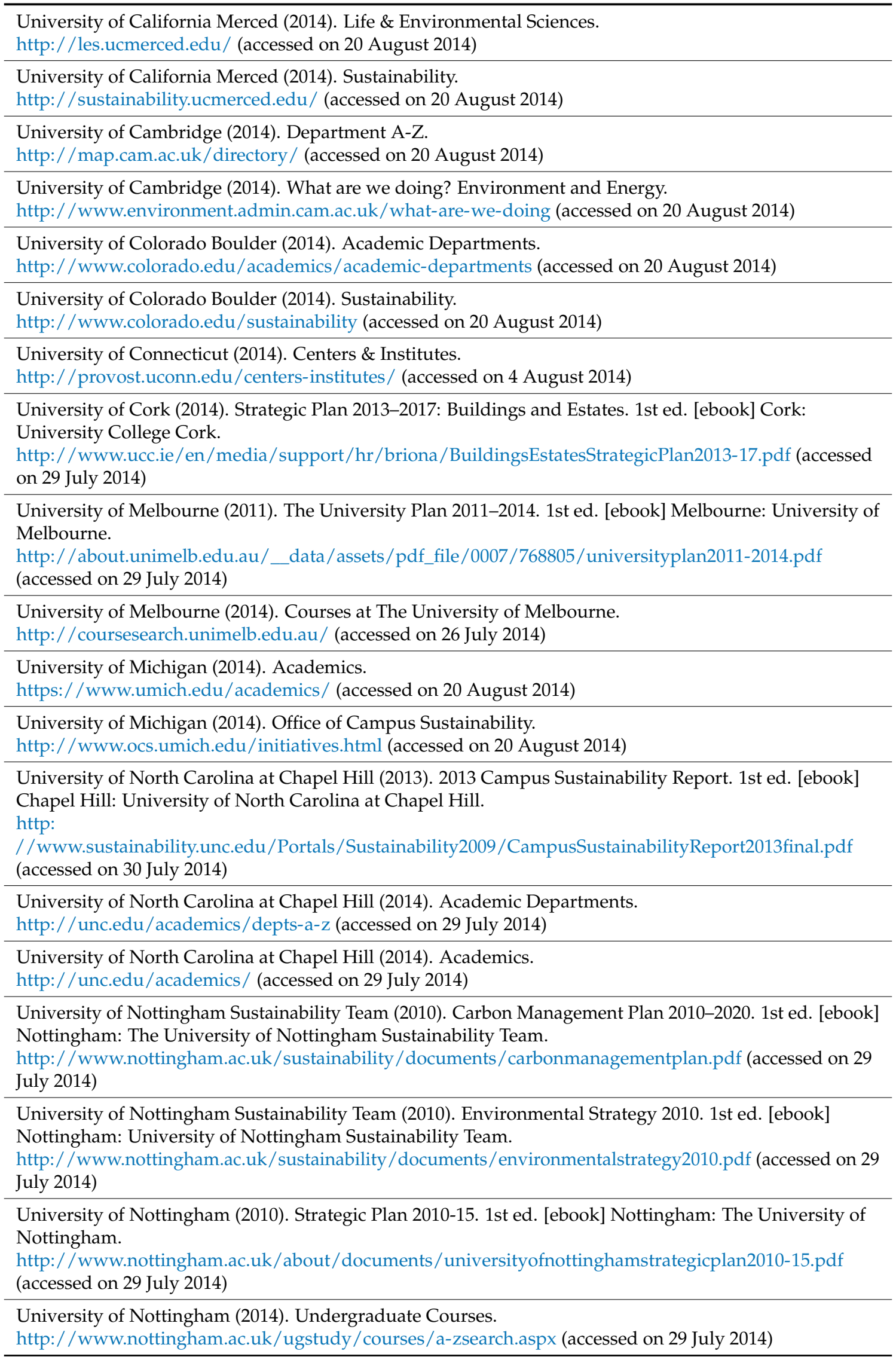


Table A6. Cont.

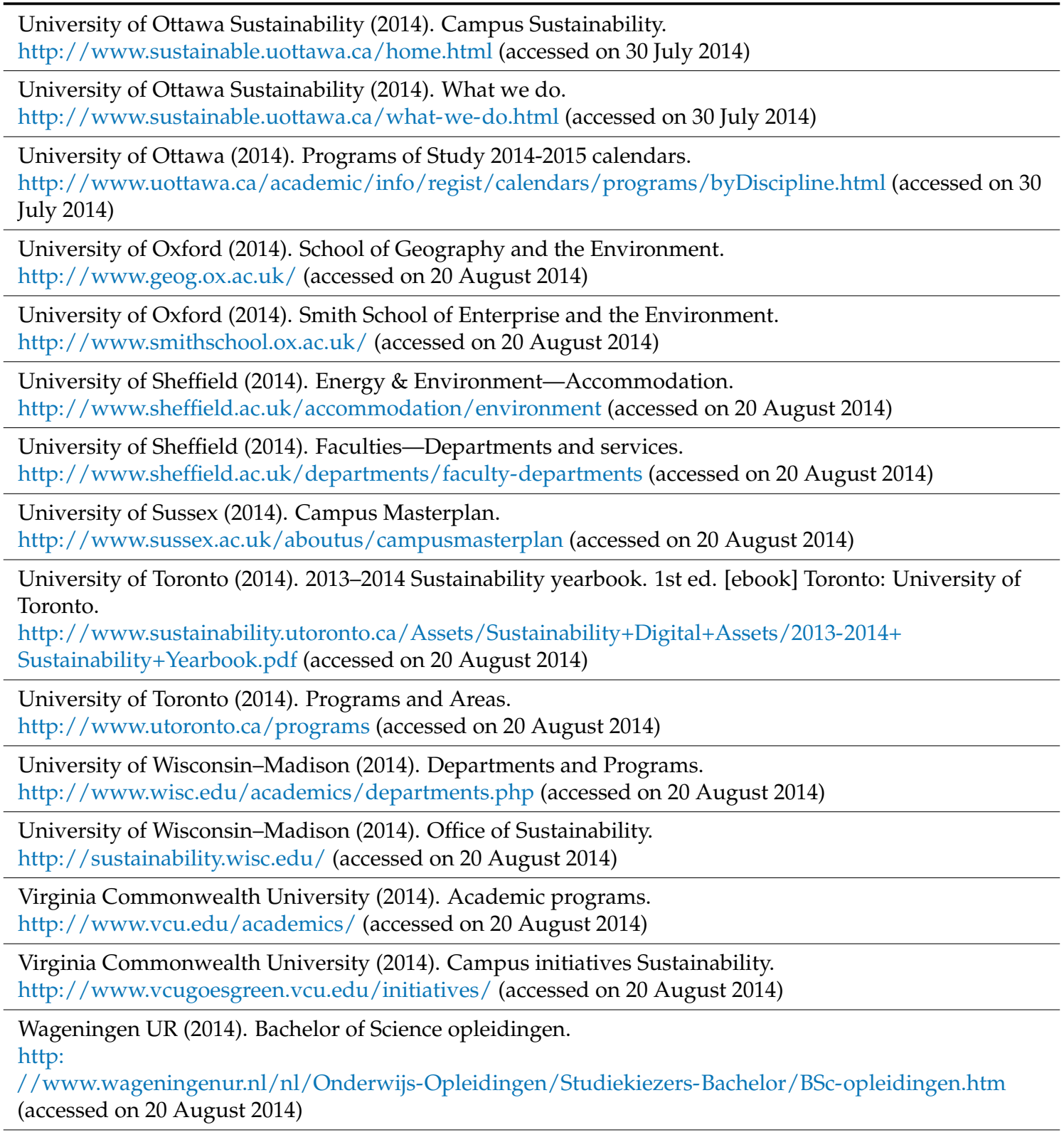
Wageningen UR (2014). Wageningen Campus.

http:/ / www.wageningenur.nl/en/Wageningen-Campus.htm (accessed on 20 August 2014)

Washington CSF (2014). Campus Sustainability Fund (CSF). Washington.edu.

http:/ / f2.washington.edu/csf / (accessed on 26 July 2014)

Washington.edu (2014). UW Undergraduate Advising: Undergraduate Majors.

http:/ / www.washington.edu/uaa/advising/majors-and-minors/list-of-undergraduate-majors / (accessed on 26 July 2014)

WU Green Dashboard (2014). University of Washington Sustainability Dashboard. Green.uw.edu. http:/ / green.uw.edu/dashboard (accessed on 26 July 2014)

Yale Sustainability (2014). Campus Projects + Action.

http:/ / sustainability.yale.edu/planning-progress/campus-projects-action (accessed on 20 August 2014)

Yale University (2014). Courses \& Registration.

http:/ / studentlife.yale.edu/academics/courses-registration (accessed on 20 August 2014) 


\section{References}

1. Pollard, S.; Turney, A.; Charnley, F.; Webster, K. The circular economy-A reappraisal of the 'stuff' we love. Geography 2016, 101, 17-27.

2. Etsy, D.; Winston, A. Green to Gold; Yale University Press: New Haven, CT, USA, 2006.

3. Kopnina, H.; Blewitt, J. Sustainable Business: Key Issues in Environment and Sustainability; Routledge: London, UK; New York, NY, USA, 2015.

4. Barbiroli, G. Eco-efficiency or/and eco-effectiveness? Shifting to innovative paradigms for resource productivity. Int. J. Sustain. Dev. World Ecol. 2006, 13, 391-395. [CrossRef]

5. Braungart, M.; McDonough, W.; Bollinger, A. Cradle to cradle design: Creating healthy emissions: A strategy for eco-effective product and system design. J. Clean. Prod. 2007, 15, 1337-1348. [CrossRef]

6. Murray, A.; Skene, K.; Haynes, K. The circular economy: An interdisciplinary exploration of the concept and application in a global context. J. Bus. Ethics 2017, 140, 369-380. [CrossRef]

7. UNEP. Circular Economy: An Alternative for Economic Development; UNEP DTIE: Paris, France, 2006; Available online: http:/ / www.unep.fr/scp/publications/details.asp?id=DTI/0919/PA (accessed on 7 July 2018).

8. WRAP. WRAP and the Circular Economy. 2017. Available online: http://www.wrap.org.uk/about-us/ about/wrap-and-circular-economy (accessed on 7 July 2018).

9. Ellen MacArthur Foundation. Towards the Circular Economy: Economic and Business Rationale for an Accelerated Transition; Ellen MacArthur Foundation: Isle of Wight, UK, 2012; Volume 1.

10. Lacy, P.; Rutqvist, J. Waste to Wealth; Palgrave Macmillan: Basingstoke, UK, 2015.

11. Moreno, M.A.; De los Rios, C.; Rowe, Z.; Charnley, F. A conceptual framework for circular design. Sustainability 2016, 8, 937. [CrossRef]

12. Hopwood, B.; Mellor, M.; O’Brien, G. Sustainable development: Mapping different approaches. Sustain. Dev. 2005, 13, 38-52. [CrossRef]

13. Goerner, S.; Voller, R. Rebuilding economic vitality. In A New Dynamic: Effective Business in a Circular Economy, 1st ed.; Ellen MacArthur Foundation: Isle of Wight, UK, 2013.

14. Mathews, J.A.; Tan, H. Progress toward a circular economy in China. J. Ind. Ecol. 2011, 15, 435-457. [CrossRef]

15. Ellen MacArthur Foundation. Towards the Circular Economy: Opportunities for the Consumer Goods Sector; Ellen MacArthur Foundation: Isle of Wight, UK, 2013; Volume 2.

16. World Business Council for Sustainable Development (WBCSD). Sustainable Business: Key Issues in Environment and Sustainability; Kopnina, H., Blewitt, J., Eds.; Routledge: London, UK; New York, NY, USA, 2015.

17. Kopnina, H.; Meijers, F. Education for Sustainable Development (ESD) Exploring Theoretical and Practical Challenges. Int. J. Sustain. High. Educ. 2014, 15, 188-207. [CrossRef]

18. Bleaney, M.; Binks, M.; Greenaway, D.; Reed, G.; Whynes, D. What does a university add to its local economy? Appl. Econ. 1992, 24, 305-311. [CrossRef]

19. Garrido-Yserte, R.; Gallo-Rivera, M. The impact of the university upon local economy: Three methods to estimate demand-side effects. Ann. Reg. Sci. 2010, 44, 39-67. [CrossRef]

20. Pastor, J.; Pérez, F.; de Guevara, J. Measuring the local economic impact of universities: An approach that considers uncertainty. High. Educ. 2013, 65, 539-564. [CrossRef]

21. Universities, UK. The Impact of Universities on the UK Economy; Higher Education in Focus; Universities UK: London, UK, 2014.

22. Khalili, N.; Duecker, S.; Ashton, W.; Chavez, F. From cleaner production to sustainable development: The role of academia. J. Clean. Prod. 2015, 96, 30-43. [CrossRef]

23. Barth, M. Many roads lead to sustainability: A process-oriented analysis of change in higher education. IJSHE 2013, 14, 160-175. [CrossRef]

24. Jackson, P.W. Life in Classrooms; Rhinehart and Winston: New York, NY, USA, 1968.

25. Humes, W. Never Discount the hidden Curriculum. 2005. Available online: http://www.tes.co.uk/article. aspx?storycode=2076639 (accessed on 11 August 2016).

26. Cotton, D.; Winter, J.; Bailey, I. Researching the hidden curriculum: Intentional and unintended messages. J. Geogr. High. Educ. 2013, 37, 192-203. [CrossRef] 
27. Barends, E.; Rousseau, D.M.; Briner, R.B. (Eds.) CEBMa Guideline for Rapid Evidence Assessments in Management and Organizations, version 1.0; Center for Evidence Based Management: Amsterdam, The Netherlands, 2017; Available online: www.cebma.org/guidelines/ (accessed on 7 July 2018).

28. UK Civil Service. What Is a Rapid Evidence Assessment. 2014. Available online: http: / / webarchive.nationalarchives.gov.uk/20140402163359/http:/ / www.civilservice.gov.uk/networks/gsr / resources-and-guidance/rapid-evidence-assessment/what-is (accessed on 6 July 2018).

29. UK Civil Service. How to Do a REA. 2014. Available online: http://webarchive.nationalarchives.gov. uk/20140402163101/http:/ / www.civilservice.gov.uk/networks/gsr/resources-and-guidance/rapidevidence-assessment/how-to-do-a-rea (accessed on 6 July 2018).

30. Thomas, J.; Newman, M.; Oliver, S. Rapid evidence assessments of research to inform social policy: Taking stock and moving forward. Evid. Policy 2013, 9, 5-27. [CrossRef]

31. Thomashow, M. The Nine Elements of a Sustainable Campus, 1st ed.; MIT Press: Cambridge, MA, USA, 2014.

32. Ellen MacArthur Foundation. Towards the Circular Economy: Accelerating the Scale-Up across Global Supply Chains; Ellen MacArthur Foundation: Isle of Wight, UK, 2014; Volume 3.

33. Ellen MacArthur Foundation; Lovins, A.B.; Braungart, M.; Stahel, W.R.; Birkeland, J.; Goerner, S.; Spicer, D.; Tuppen, C.; Voller, R.; Webster, K.; et al. A New Dynamic: Effective Business in a Circular Economy, 1st ed.; (Chapter 1); Ellen MacArthur Foundation: Isle of Wight, UK, 2013.

34. GreenMetric. 2013 UI GreenMetric World University Ranking. 2013. Available online: http:/ /greenmetric.ui. ac.id/ranking/year/2013 (accessed on 11 August 2016).

35. Ragazzi, M.; Ghindini, F. Environmental sustainability of universities: Critical analysis of a green ranking. Energy Procedia 2017, 119, 111-120. [CrossRef]

36. QS Top Universities. QS World University Rankings by Subject 2013—Environmental Sciences. 2013. Available online: http:/ / www.topuniversities.com/university-rankings/university-subject-rankings/2013/ environmental-studies (accessed on 11 August 2016).

37. Müller-Christ, G.; Sterling, S.; van Dam-Mieras, R.; Adomßent, M.; Fischer, D.; Rieckmann, M. The role of campus, curriculum, and community in higher education for sustainable development-a conference report. J. Clean. Prod. 2013, 62, 134-137. [CrossRef]

38. Edman, J.; Lynch, W.; Yates, A. The impact of exercise performance dissatisfaction and physical exercise on symptoms of depression among college students: A gender comparison. J. Psychol. 2014, 148, $23-35$. [CrossRef] [PubMed]

39. Scheier, M.; Carver, C. Effects of optimism on psychological and physical well-being: Theoretical overview and empirical update. Cogn. Ther. Res. 1992, 16, 201-228. [CrossRef]

40. Winter, J.; Cotton, D. Making the hidden curriculum visible: Sustainability literacy in higher education. Environ. Educ. Res. 2012, 18, 783-796. [CrossRef]

41. Almeida, C.; Santos, A.; Bonilla, S.; Giannetti, B.; Huisingh, D. The roles, perspectives and limitations of environmental accounting in higher educational institutions: An emergy synthesis study of the engineering programme at the Paulista University in Brazil. J. Clean. Prod. 2013, 52, 380-391. [CrossRef]

42. Murphy, T.; O'Brien, W. A strategic decision model for evaluating college and university sustainability investments. Manag. Res. Rev. 2014, 37, 2-18. [CrossRef]

43. White, S.; Park, Y.; Israel, T.; Cordero, E. Longitudinal evaluation of peer health education on a college campus: Impact on health behaviors. J. Am. Coll. Health 2009, 57, 497-506. [CrossRef] [PubMed]

44. Li, S. The research on quantitative evaluation of circular economy based on waste input-output analysis. Procedia Environ. Sci. 2012, 12, 65-71. [CrossRef]

45. Fry, J.; Lenzen, M.; Giurco, D.; Pauliuk, S. An Australian multi-regional waste supply-use framework. J. Ind. Ecol. 2015, 20. [CrossRef]

46. Wood, R.; Lenzen, M. An application of an improved ecological footprint method and structural path analysis in a comparative institutional study. Local Environ. 2003, 8, 365-384. [CrossRef]

47. Charnley, F.; Lemon, M.; Evans, S. Exploring the process of whole system design. Des. Stud. 2011, 32, $156-179$. [CrossRef]

48. The Carbon Trust. Further and Higher Education: Training Colleges and Universities to Be Energy Efficient. 2012. Available online: http://www.carbontrust.com/media/39208/ctv020_further_and_higher_education. pdf (accessed on 11 August 2016). 
49. DECC. The Energy Efficiency Strategy: The Energy Efficiency Opportunity in the UK; Department of Energy and Climate Change: London, UK, 2012.

50. HEFCE. Revolving Green Fund-HEFCE. 2014. Available online: http://www.hefce.ac.uk/whatwedo/ $\mathrm{lgm} / \mathrm{sd} / \mathrm{rgf} /$ (accessed on 11 August 2016).

51. Atkins. Revolving Green Fund 3 Application Assessments and Outcomes: A Report to HEFCE. 2013. Available online: http://www.hefce.ac.uk/media/hefce/content/pubs/indirreports/2013/ RGF3,Application, assessments, and, outcomes/Revolving\%20Green\%20Fund\%203\%20Application\% 20assessments\%20and\%20outcomes.pdf (accessed on 7 July 2018).

52. Ofgem. Feed in Tariffs. Available online: https://www.ofgem.gov.uk/environmental-programmes/fit/fittariff-rates (accessed on 7 July 2018).

53. Sheth, J.; Sethia, N.; Srinivas, S. Mindful consumption: A customer-centric approach to sustainability. J. Acad. Mark. Sci. 2011, 39, 21-39. [CrossRef]

54. Morgan, J. Who's in the money? Times Higher Education, 201414 March; 43-51.

55. Environmental Health and Engineering. Profiting through Campus Sustainability: Financial Tools and Strategies; Environmental Health \& Engineering: Needham, MA, USA, 2014.

56. UUK. The Funding Environment for Universities: An Assessment; New Horizons; Universities UK: London, UK, 2013.

57. Audretsch, D. From the entrepreneurial university to the university for the entrepreneurial society. J. Technol. Transf. 2014, 39, 313-321. [CrossRef]

58. Ateş, M.; Bloemhof, J.; van Raaij, E.; Wynstra, F. Proactive environmental strategy in a supply chain context: The mediating role of investments. Int. J. Prod. Res. 2012, 50, 1079-1095. [CrossRef]

59. Brown, D.; Fee, C.; Thomas, S. Financial leverage and bargaining power with suppliers: Evidence from leveraged buyouts. J. Corp. Financ. 2009, 15, 196-211. [CrossRef]

60. Baboulet, O.; Lenzen, M. Evaluating the environmental performance of a university. J. Clean. Prod. 2010, 18, 1134-1141. [CrossRef]

61. Tate, W.; Ellram, L.; Gölgeci, I. Diffusion of environmental business practices: A network approach. J. Purch. Supply Manag. 2013, 19, 264-275. [CrossRef]

62. Hardesty, S.; Allen, P.; Feenstra, G.; Ohmart, J.; Perkins, T.; Perez, J. Institutional food distribution systems: Bringing students, farmers, and food service to the table. J. Food Distrib. Res. 2010, 41, 58-63.

63. Orme, J.; Dooris, M. Integrating health and sustainability: The higher education sector as a timely catalyst. Health Educ. Res. 2010, 25, 425-437. [CrossRef] [PubMed]

64. Simkins, G.; Nolan, A. Environmental Management System in Universities; Occasional Paper for the Environmental Association for Universities and Colleges; EAUC: Cheltenham, UK, 2004.

65. Alshuwaikhat, H.; Abubakar, I. An integrated approach to achieving campus sustainability: Assessment of the current campus environmental management practices. J. Clean. Prod. 2008, 16, 1777-1785. [CrossRef]

66. Zhang, N.; Williams, I.D.; Kemp, S.; Smith, N.F. Greening academia; developing sustainable waste management at higher education institutions. Waste Manag. 2011, 31, 1606-1616. [CrossRef] [PubMed]

67. Insight University of Gloucestershire. ISO14001-The University Environmental Management System. 2014. Available online: http://insight.glos.ac.uk/sustainability/practice/Pages/ UniversityEnvironmentalManagementSystem.aspx (accessed on 11 August 2016).

68. Ghosh, S.; Buckler, L.; Skibniewski, M.; Negahban, S.; Kwak, Y. Organizational governance to integrate sustainability projects: A case study. Technol. Econ. Dev. Econ. 2014, 20, 1-24. [CrossRef]

69. Cornelli, F.; Kominek, Z.; Ljungqvist, A. Monitoring managers: Does it matter? J. Financ. 2013, 68, $431-481$. [CrossRef]

70. Wahlén, C.B. Constructing conservation impact: Understanding monitoring and evaluation in conservation NGOs. Conserv. Soc. 2014, 12, 77-88. [CrossRef]

71. Epstein, M.; Widener, S. Facilitating sustainable development decisions: Measuring stakeholder reactions. Bus. Strategy Environ. 2011, 20, 107-123. [CrossRef]

72. Gauthier, J.; Wooldridge, B. Influences on sustainable innovation adoption: Evidence from leadership in energy and environmental design. Bus. Strategy Environ. 2012, 21, 98-110. [CrossRef]

73. Block, T.; Paredis, E. Urban development projects catalyst for sustainable transformations: The need for entrepreneurial political leadership. J. Clean. Prod. 2013, 50, 181-188. [CrossRef] 
74. Crow, M. What Is the Role of Universities in Global Development? 2014. Available online: http://blogs. worldbank.org/education/what-role-universities-global-development (accessed on 11 August 2016).

75. Lebeau, Y.; Bennion, A. Forms of embeddedness and discourses of engagement: A case study of universities in their local environment. Stud. High. Educ. 2014, 39, 278-293. [CrossRef]

76. Orr, D. Can educational institutions learn? The creation of the Adam Joseph Lewis Centre at Oberlin College. In Sustainability on Campus: Stories and Strategies for Change; Bartlett, P.F., Chase, G.W., Eds.; MIT Press: London, UK, 2004; pp. 159-176.

77. Haidet, P.; Stein, H. The role of the student-teacher relationship in the formation of physicians. J. Gen. Intern. Med. 2006, 21, 16-20. [CrossRef] [PubMed]

78. Blasco, M. Aligning the hidden curriculum of management education with PRME: An inquiry-based framework. J. Manag. Educ. 2012, 36, 364-388. [CrossRef]

79. Thompson, L.; Clark, G.; Walker, M.; Whyatt, J. It's just like an extra string to your bow: Exploring higher education students' perceptions and experiences of extracurricular activity and employability. Act. Learn. High. Educ. 2013, 14, 135-147. [CrossRef]

80. Leyden, D.; Link, A. Knowledge spill overs, collective entrepreneurship, and economic growth: The role of universities. Small Bus. Econ. 2013, 41, 797-817. [CrossRef]

81. Williams, L.; Turner, N.; Jones, A. Embedding Universities in Knowledge Cities. Ideopolis and Knowledge Economy Programme Paper. The Work Foundation. 2008. Available online: http:/ / www.theworkfoundation. com/DownloadPublication/Report/208_208_ideopolis_education061208.pdf (accessed on 11 August 2016).

82. University of Ottawa. Campus Sustainability. 2014. Available online: http://www.sustainable.uottawa.ca/ home.html (accessed on 11 August 2016).

83. University of Nottingham. Environmental Strategy 2010, 1st ed.; University of Nottingham Sustainability Team: Nottingham, UK, 2010; Available online: http:/ / www.nottingham.ac.uk/sustainability/documents / environmentalstrategy2010.pdf (accessed on 11 August 2016).

84. University of Bradford. Inspirational Building. 2014. Available online: http://www.bradford.ac.uk/ recentre/about-us/inspirational-building/ (accessed on 5 August 2014).

85. White, S. Campus sustainability plans in the United States: Where, what, and how to evaluate? Int. J. Sustain. High. Educ. 2014, 15, 228-241. [CrossRef]

86. Bartolomeo, M.; dal Maso, D.; de Jong, P.; Eder, P.; Groenewegen, P.; Hopkinson, P.; James, P. Eco-efficient producer services-What are they, how do they benefit customers and the environment and how likely are they to develop and be extensively utilised? J. Clean. Prod. 2003, 11, 829-837. [CrossRef]

87. De los Rios, I.C.; Charnley, F. Skills and capabilities for a sustainable and circular economy: The changing role of design. J. Clean. Prod. 2017, 160, 109-122. [CrossRef]

88. Building Research Establishment. BREEAM. 2016. Available online: http://www.breeam.com (accessed on 11 August 2016).

89. iFixit. The Free Repair Guide for Everything written by Everyone. 2016. Available online: https://www. ifixit.com (accessed on 11 August 2016).

90. Ellen MacArthur Foundation. The Circular Economy 100 Programme. 2017. Available online: https: / / www.ellenmacarthurfoundation.org/ce100/the-programme/networking (accessed on 7 July 2018).

91. UK Government. New Designs for a Circular Economy. 2016. Available online: https://innovateuk.blog. gov.uk/2016/04/14/new-designs-for-a-circular-economy/ (accessed on 7 July 2018).

(C) 2018 by the authors. Licensee MDPI, Basel, Switzerland. This article is an open access article distributed under the terms and conditions of the Creative Commons Attribution (CC BY) license (http://creativecommons.org/licenses/by/4.0/). 